\title{
TEMPEST: 音楽的表現が可能な文字入カシステム
}

\author{
竹川佳成 \\ 寺田努†b) \\ 塚本昌彦 $\dagger \dagger \mathrm{c}$ \\ 西尾章治郎)
}

TEMPEST: A Text Input System with Musical Expression

Yoshinari TAKEGAWA ${ }^{\dagger a)}$, Tsutomu TERADA ${ }^{\dagger b)}$, Masahiko TSUKAMOTO ${ }^{\dagger \dagger c)}$, and Shojiro NISHIO ${ }^{\dagger d}$

あらまし: 近年, 計算機の普及に伴い, 電子メール, ブログ, チャットなどテキストベースのコミュニケーション が活発に行われている.また，感情や込めたい思いをより良く表現し他者に伝えるために，写真，ムービー，効果 音, 音楽, 香りなどさまざまなコミュニケーションメディアやインタフェース, システムが提案されてきた。一 方，ピアニストは鍵盤楽器を使って感情や思いを巧みに表現している。したがって, 文字入力に演奏者の音楽的 な表現力を付加できれば，感情や思いをより豊かに表現・伝達できると考えられる.光こで本研究では，鍵盤を 使って文字入力に音楽表現を付加できる文字入カシステム TEMPEST (TExt input and Musical PErforming SysTem) を提案する. TEMPEST の文字入力方式は, 楽器演奏による感情伝達を考慮した設計になっており ユーザはあたかも演奏しているかのように文字入力できる.さらに，実装したプロトタイプを用いた，文字入力 演奏の視聴評価実験の結果から，提案システムは感情伝達手段として有効であることが証明された 。 キーワード : 文字入力 , 鍵盤楽器, 感情表現, 音楽表現

\begin{abstract}
Recently, due to the widespread use of computers, text-based communication methods, such as e-mail, blog, and chat, have attracted a great deal of attention. Moreover, various communication media, such as picture and movie, are used for expressing own emotion. If pianists can apply their musical expressions to the text input, they can input texts with their own emotion richly. Therefore, the goal of our study is to construct TEMPEST (TExt input and Musical PErforming SysTem) that is a text input system to input texts with various musical expressions by using a MIDI keyboard. Since this system provides text input methods considering musical artistry, a performer can input texts like playing music. As the result of a questionnaire evaluation, it proves that proposed methods have high effectiveness for expressing emotion in inputting texts.
\end{abstract}

Keywords: Text Input, Keyboard Instrument, Emotion Expression, Musical Expression

\section{1.はじめに}

近年 , 計算機の普及およびネットワーク環境の整備 に伴い，電子メール，ブログ, チャットなどテキスト ベースのコミュニケーションが活発に行われている． また，感情や思いをより良く表現し他者に伝えるため に,写真 , ムービー, 効果音, 音楽 , 香りなどのコミュ ニケーションメディアやインタフェース , システムが 研究開発されてきた [6], [11], [19], [20], [23], [24] .

一方，演奏者の感情や思いを的確に表現し，効果的 に他者へ伝達できるインタフェースの 1 つに楽器が ある. 楽器はある特定の音色の音をいくつかの周波数 について出すことしかできないが , この単純さのゆえ

\footnotetext{
$\dagger$ 大阪大学大学院情報科学研究科

Graduate School of Information Science and Technology, Osaka University

门†神戶大学大学院工学研究科

Graduate School of Engineering, Kobe University

a) E-mail: takegawa@ist.osaka-u.ac.jp

b) E-mail: tsutomu@ist.osaka-u.ac.jp

c) E-mail: tuka@kobe-u.ac.jp

d) E-mail: nishio@ist.osaka-u.ac.jp
}

に使い方の自由度は非常に高く，表現の幅は広い，光 のため，演奏者はより深く豊かな表現の実現を目指し 日々鍛錬している．したがって，文字入力に楽器演奏 者の音楽的な表現力を付加できれば，感情や思いをよ り豊かに表現・伝達できると考えられる．

弚こで本研究では, 鍵盤奏者を対象とし, 文字入力 に音楽表現を付加できる文字入カシステム TEMPEST (TExt input and Musical PErforming SysTem)を 提案する.TEMPEST は，インタフェースとして鍵 盤楽器を採用し, 音楽表現に注力した文字入力方式を 提案することて鍵盤奏者がこれまでに習得した音楽表 現技術を転用できるため，文字と演奏による豊かな感 情表現および効果的な感情伝達を実現している .

以下，2 章で TEMPEST の設計について説明し , 3 章で実装について述べ，4 章で TEMPEST の評価に ついて説明する . 最後に 5 章で本研究のまとめを行う .

\section{TEMPEST の設計}

TEMPEST では文字入力のスピードや正確性を重 視する一般の文字入力インタフェースとは異なり，い かに思いや感情を演奏として表現できるかという点が 
重要になる . 光のためにはユーザが任意の文字を好き なタイミングで入力でき，产のときの出力音を自由に コントロールできることが望ましい.しかし，携帯電 話やポケットベルのような文字入力方式では入力文字 に対して使用するキーが決まっているため，文字に対 する出力音が固定され，ユーザの意図しない音楽が生 成される.この問題を解決する方法として次の 2 つが 考えられる 。

\section{文字入力鍵の打鍵音の変更}

これは，文字入力鍵 $($ 打鍵時に文字と楽音を生成する 鍵) の打鍵音 (鍵の打鍵により出力される音) を変更 する方式である . 例えば，演奏鍵（文字入力に用いな (鍵) の演奏と協和する音を文字入力鍵の打鍵音に割 り当てる方法が考えられる．このようにすることで， ユーザは演奏鍵の演奏を通して間接的に文字入力音を コントロールできる．ただし，鍵と炎の出力音の関係 がくずれるため演奏に違和感が生じる .

\section{中継音の挿入}

これは，聴きづらい音列にならないように手動で文字 入力と文字入力の間に音楽的にうまくつながるように 中継音を挿入する方式である . 本方式では, 文字入力 音間，連結音間，文字入力音と連結音間における音の 連結のしやすさを意識し，入力文字に割り当てる音の マッピングや中継音を文字入力方式設計時に考慮する 必要がある

本方式は，鍵と光の出力音の関係を崩すことなく音 楽的な文字入力を実現できるが, 次の文字入力音と中 継音の中から望む音楽表現を満たす最適な音を選択す るなどユーザが一度に考えなければならない負荷が増 えてしまう.また，中継音を挿入するため，いつでも 好きなときに文字を入力できない .

これらの方法は光れ光れ利点・欠点があり，どちら が最適か決めるのは困難であるため, 本研究では両 方式を選択的に利用できる文字入カシステムを設計 し，感情伝達手段として有効であるか検証する．以下， TEMPEST の設計方針について説明する .

\section{1 設 計方 針}

\section{文字入力のための入力要素}

演奏中にリアルタイムに抽出でき , 入力文字を決定 するための文字入力情報は，ノートナンバー，ベロシ ティ, 弾いている手 (右手か左手か), 運指, 鍵上の打 鍵位置などがある．また，時系列も考慮すると音長， 音長の組合せであるリズム，和音の打鍵タイミングな ども取得できる .

本システムでは, 最も安定した情報を取得できる ノートナンバーを文字入力情報として利用する .ベロ シティやリズム , 音長といった要素は, 個人差がある ためあらかじめキャリブレーションが必要であったり， 兴の日の体調などに左右されるため, 細かい制御が 難しい，また，運指や弾いている手は，認識に特殊な ハードウェアを必要とし, 正確な検出が困難である .

ハードゥェア

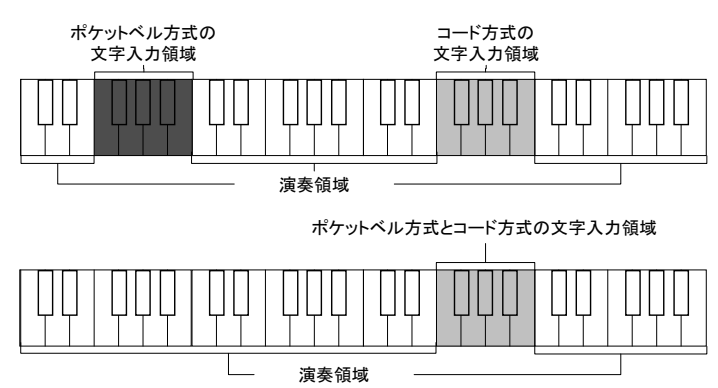

图 1 文字入力領域と演奏領域の配置

TEMPEST はあらゆる状況で広く利用することを想 定し，2 オクターブ以上の音域をもつ MIDI キーボー ドなら TEMPEST の全機能を利用できるように設計 する．また，TEMPEST が利用する情報は MIDI キー ボードが生成する MIDI ノートオンおよびオフ情報の みで, 特別なデバイスは不要である.

\section{文字入力方式の検討}

TEMPEST が入力できる文字は, かな文字, 英数字 および Shift , Ctrl , Alt など特殊文字である .

これまで提案されてきたキー入カインタフェースで は，一般の PC 用キーボードのように 1 つのキーに 1 つの文字が割り当てられる方式 (QWERTY 方式), 同じキーを複数回押すことで入力文字を選択する方 式 (携帯電話方式)，子音と母音など複数キーの組み合 わせで入力する方式 (ポケットベル方式)，複数キーを 同時に入力する方式 (コード方式) が利用されている QWERTY 方式はもつともシンプルな文字入力方式 であるが, 鍵盤数が少ないキーボードには適さない． また，携帯電話方式は同じキーの連続入力が多く，演 奏として成り立ちにくい．したがって，本研究ではポ ケットベル方式とコード方式を用いた文字入力方式を 提案する。

\section{文字入力領域の配置}

TEMPEST が必要な文字入力パターン数は, 文字セッ 卜の数がもつとも多いかな文字の 46 パターンに「モー ド切替」，「変換」を加えた 48 パターンである．し たがって，必要な鍵数は，ポケットベル方式では，子 音と母音の 2 ストロークで入力する場合，最低 7 鍵 $(7 * 7=49$ パターン)，コード方式では， 2 和音， 3 和音の入力を考えた場合，最低 7 鍵 $\left({ }_{7} C_{3}+{ }_{7} C_{2}=56\right.$ パターン) あればよい。

想定する鍵盤では演奏鍵と文字入力鍵が混在する． ここで, 文字入力鍵が集まっている領域を文字入力領 域，演奏鍵が集まっている領域を演奏領域と呼び，こ れらの領域の配置は図 1 に示すように文字入力領域の 複数配置 (図 1 の上段), 異なる文字入力方式の文字入 力領域の重畳 (図 1 の下段) など配置はユーザが任意 に設定できる .

このように，TEMPEST では鍵盤上に多樣な文字 入力方式の文字入力領域を同時に割り当てることがで き，1 つの文字に対しさまざまな奏法を用いることが 


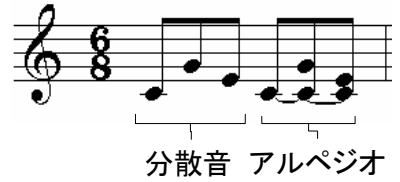

図 2 伴奏の奏法

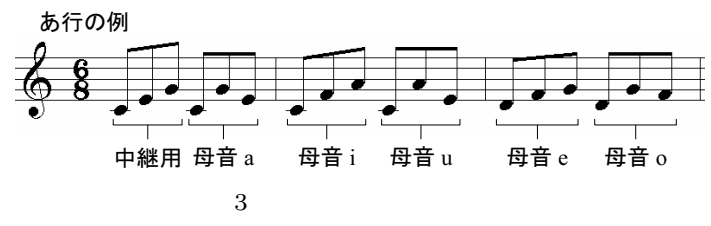

当てを示す. 紙面の都合上 , 英数字, 特殊文字の文字 コード割当ては省略した . 伴奏方式は，図 2 に示すよ うに分散和音とアルペジオの 2 つの奏法を使い分け て入力する . 表中で下線が引かれている階名はアルペ ジオで演奏する．また，表中でダブルクォーテーショ ンマーク付音名はダブルクォーテーションマークが付 いていない音名より高い音高であることを示す．した がって，伴奏方式で必要な鍵数は C 鍵から $\mathrm{E} ”$ 鍵の 17 鍵である . また，文字入力による調性の乱れを防ぐた めに, 文字入力鍵は白鍵を用いた．さらに，図 3 に示 すように母音に対して伴奏形を統一することで文字入 力の習得を容易にしている. 加えて, 文字が入力され ないコードや図 3 の左端に示す中継用の伴奏形を用い ることで音楽的なコード進行を実現できる．

提案文字指定方式の比較

単音方式は, 表情付けを巧みに行うことでメロディ パートとして活用できる。また， 2 和音， 3 和音を演 奏する和音方式と組み合わせることで文字入力中でも さまざまな表現が可能となる．しかし，前節で述べた ように文字に対して使用する鍵が決まっているため， ユーザの意図しない音楽が生成されてしまう.

伴奏方式は, コードに文字をマッピングすることで， 文字入力による不協和音の生成を防いでいる.しかし， 連続して文字入力を行う場合，コード進行が乱れてし まうため文字が入力されないコードや伴奏形を挿入し コード進行を考慮しながら文字入力する必要がある．

2.3 ノートナンバー変更アルゴリズム

本研究では上記の単音方式や和音方式における聴き づらさを解決するために，文字入力鍵に割り当てられ ているノートナンバーを演奏領域で弾いているノー トナンバーに応じて変化させる方式を提案する.具体 的には , 演奏領域で弾いている音と不協和音にならな い音集合を導出し，文字入力領域に乥れらの音を敷き 詰めることで，ユーザが間接的に文字入力音をコント ロールできるようにする .

なお，下記アルゴリズムは文字入力領域単位に適用 される .

階名の割当て

(1) ランダム方式

文字入力領域のある鍵が打鍵された場合，演奏領域で 弾いている鍵の階名をランダムに選択し割り当てる . 例えば，図 4 に示す状況で, 演奏領域の C3，E3，G3 の鍵が弾かれている場合, システムはランダムに C , $\mathrm{E}, \mathrm{G}$ から打鍵された文字入力鍵の階名を選ぶ。

(2) ダイレクト方式

演奏領域で弾いている鍵の低い音高の階名から順に文 
表 1 提案文字入力方式

(a) 単音方式

\begin{tabular}{|c|c|c|c|c|c|c|}
\hline $\begin{array}{c}\text { かな文字 } \\
\text { 第2 }\end{array}$ & $\bar{C}$ & C\# & & D\# & $\bar{E}$ & $\bar{F}$ \\
\hline $\mathrm{C}$ & 㐫 & い & 5 & え & 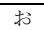 & Enter \\
\hline $\mathrm{C \#}$ & か & き & $<$ & it & $=$ & Space \\
\hline D & さ & l & す & せ & z & Back \\
\hline D\# & た & ち & o & $\tau$ & と & MS \\
\hline E & な & に & $\not 2$ & 权 & の & IC \\
\hline $\mathrm{F}$ & は & ひ & ふ & $\sim$ & ほ & \\
\hline F\# & ま & み & む & め & 屯 & \\
\hline G & や & , & $\Phi$ & . & よ & \\
\hline G\# & 5 & v & る & れ & 万 & \\
\hline A & わ & を & L & $!$ & $?$ & \\
\hline \multicolumn{7}{|l|}{ 英数字 } \\
\hline 第1音第2 & $\overline{c \mathrm{C}}$ & 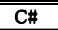 & $\bar{D}$ & D\# & $\bar{E}$ & $\bar{F}$ \\
\hline $\mathrm{C}$ & $\mathrm{a}$ & b & $\mathrm{c}$ & $\mathrm{d}$ & $\mathrm{e}$ & Enter \\
\hline $\mathrm{C \#}$ & f & $\mathrm{g}$ & $\mathrm{h}$ & i & $j$ & Space \\
\hline D & $\mathrm{k}$ & 1 & $\mathrm{~m}$ & $\mathrm{n}$ & o & Back \\
\hline D\# & $\mathrm{p}$ & q & $\mathrm{r}$ & $\mathrm{s}$ & t & MS \\
\hline E & $\mathrm{u}$ & $\mathrm{v}$ & w & $\mathrm{x}$ & y & IC \\
\hline F & $\mathrm{z}$ & ! & ? & . & , & \\
\hline $\mathrm{F} \#$ & 1 & 2 & 3 & 4 & 5 & \\
\hline G & 6 & 7 & 8 & 9 & 0 & \\
\hline G\# & + & - & * & I & $=$ & \\
\hline A & ( & ) & \{ & \} & $\hat{\imath}$ & \\
\hline \multicolumn{7}{|l|}{ 特殊文字 } \\
\hline 第1音第2 & $\overline{\bar{C}}$ & $\overline{C \text { C\# }}$ & $\bar{D}$ & D\# & $\bar{E}$ & $\overline{\mathrm{F}}$ \\
\hline C & Esc & Tab & Ctrl & Shift & Alt & Enter \\
\hline $\mathrm{C} \#$ & PrSc & Del & Pgup & PgDn & Ins & Space \\
\hline D & ScrLk & Pause & Home & End & $¥$ & Back \\
\hline D\# & {[} & ] & \# & $\$$ & $\%$ & MS \\
\hline E & $\&$ & | & $\sim$ & - & @ & IC \\
\hline $\mathrm{F}$ & $<$ & $>$ & ; & & & \\
\hline F\# & $\leftarrow$ & $\uparrow$ & & $\downarrow$ & $\rightarrow$ & \\
\hline G & F1 & $\mathrm{F} 2$ & F3 & F4 & F5 & \\
\hline G\# & F6 & F7 & F8 & F9 & F10 & \\
\hline A & F11 & $\mathrm{F} 12$ & & & " & \\
\hline
\end{tabular}

(b) 和音方式

\begin{tabular}{|c|c|c|c|c|c|}
\hline かな文字 & " C\# & 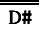 & 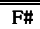 & "G\# & $\bar{~} \overline{\text { A\# }}$ \\
\hline $\mathrm{C}$ & 㐫 & い & 5 & え & お \\
\hline C, D & か & き & $<$ & H & $=$ \\
\hline D & さ & ᄂ & す & せ & そ \\
\hline $\mathrm{D}, \mathrm{E}$ & た & $\hbar$ & 0 & $\tau$ & と \\
\hline E & な & に & ぬ & 权 & の \\
\hline E, F & は & ひ & ふ & 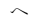 & ほ \\
\hline $\mathrm{F}$ & ま & み & む & め & 屯 \\
\hline$F, G$ & や & , & ゆ & & よ \\
\hline G & 5 & b & る & れ & 万 \\
\hline G, A & わ & を & $h$ & ! & $?$ \\
\hline
\end{tabular}

\begin{tabular}{c|ccccc}
\hline \hline 英数字 & C\# & D\# & F\# & G\# & A\# \\
\hline C & a & b & c & d & e \\
C, D & f & g & h & i & j \\
D & k & l & m & n & o \\
D, E & p & q & r & s & t \\
E & u & v & w & x & y \\
E, F & z & ! & $?$ & . & , \\
F & 1 & 2 & 3 & 4 & 5 \\
F, G & 6 & 7 & 8 & 9 & 0 \\
G & + & - & $*$ & $/$ & $=$ \\
G, A & ( & ) & \{ & \} & f \\
A & Enter & Space & Back & MS & IC \\
\multicolumn{7}{l}{}
\end{tabular}

\begin{tabular}{c|ccccc}
\hline \hline 特殊文字 & C\# & D\# & F\# & G\# & A\# \\
\hline C & Esc & Tab & Ctrl & Shift & Alt \\
C, D & PrSc & Del & PgUp & PgDn & Ins \\
D & ScrLk & Pause & Home & End & $¥$ \\
D, E & {[} & ] & $\#$ & $\$$ & $\%$ \\
E & $\&$ & $\mid$ & $\sim$ & - & $@$ \\
E, F & $<$ & $>$ & $;$ & $\vdots$ & \\
F & $\leftarrow$ & $\uparrow$ & & $\downarrow$ & $\rightarrow$ \\
F, G & F1 & F2 & F3 & F4 & F5 \\
G & F6 & F7 & F8 & F9 & F10 \\
G, A & F11 & F12 &, & & $"$ \\
A & Enter & Space & Back & MS & IC \\
\hline
\end{tabular}

(c) 伴奏方式

かな文字

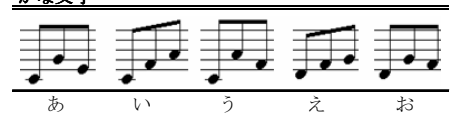

\begin{tabular}{ccccc}
$\mathrm{C}, \mathrm{G}, \mathrm{E}$ & $\mathrm{C}, \mathrm{F}, \mathrm{A}$ & $\mathrm{C}, \mathrm{A}, \mathrm{F}$ & $\mathrm{D}, \mathrm{F}, \mathrm{G}$ & $\mathrm{D}, \mathrm{G}, \mathrm{F}$ \\
\hline か & き & $<$ & け & $こ$
\end{tabular}

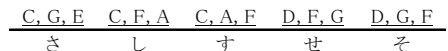

\begin{tabular}{ccccc} 
D, A, F & D, G, H & D, H, G & E, G, A & E, A, G \\
\hline$\hbar$ & $\hbar$ & $つ$ & $\tau$ & $\zeta$
\end{tabular}

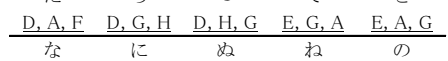
\begin{tabular}{ccccc} 
E, H, G & E, A, C" & E, C", A & F, A, H & F, H, A \\
\hline は & $ひ$ & ふ & $へ$ & ほ
\end{tabular}

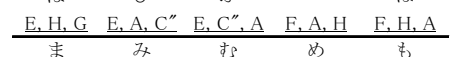
\begin{tabular}{cccc} 
F, C", A & F, H, D" & F, D", H & G, H, C" \\
\hline$や$ & G, C", H
\end{tabular} $\frac{\underline{F, C^{\prime \prime}, A}}{\zeta} \frac{F, H^{\prime}, D^{\prime \prime}}{\eta} \frac{F, D^{\prime \prime}, H}{\precsim} \frac{G, H, C^{\prime \prime}}{れ} \frac{G, C^{\prime \prime}, H}{\zeta}$ $\frac{G, D^{\prime \prime}, H \text { G, C", E" G, E", C" A, C", D" A, D", C" }}{\hbar}$ $\frac{G, D^{\prime \prime}, H}{\text { Enter }} \frac{G, C^{\prime \prime}, E^{\prime \prime}}{\text { Space }} \frac{G, E^{\prime \prime}, C^{\prime \prime}}{\text { Back }} \frac{A, C^{\prime \prime}, D^{\prime \prime}}{\text { MS }} \frac{A, D^{\prime \prime}, C^{\prime \prime}}{\text { IC }}$ A, E", C" A, D", F" A, F", D" H, D", E" H, E", D"

MS : モード切替 IC : 変換
字入力領域の階名として割り当てる．例えば，図 5 に 示すように演奏領域の C3，E3，G3 の鍵が弾かれた 場合, システムは文字入力領域の左端から $\mathrm{C}, \mathrm{E}, \mathrm{G}$ の順で敷き詰める .

(3) コード推定方式

コード推定方式は, 演奏領域で弾いている階名の構成 を包含するコードを検索し，候補となるコード群から 1 つを選んで, 兴のコード構成音をダイレクト方式と 同樣の方法で敷きつめる . 例えば , 図 6 に示すように 演奏領域の C3，E3，G3 の鍵か弾かれた場合，候補と なるコード - C (C major triad), CMaj7 (C major seventh) , C7 (C dominant seventh), C6 (C major sixth) からランダムに 1 つ選択し，ダイレクト方式と 同樣の手順で文字入力領域に割り当てる .

ランダム方式では, 文字入力領域の各鍵に关の都度 違った階名か割り当てられ, ユーザは意外性のある演 奏を楽しめる.一方, 割当て音は, 演奏領域で弾いて いる音か割り当てられることは予測できるが，正確な 演奏のコントロールが難しい . ダイレクト方式は , 演 奏領域で弾いている階名が同じであれば, 文字入力領 域には同じ階名が割り当てられるため, 意図した演奏

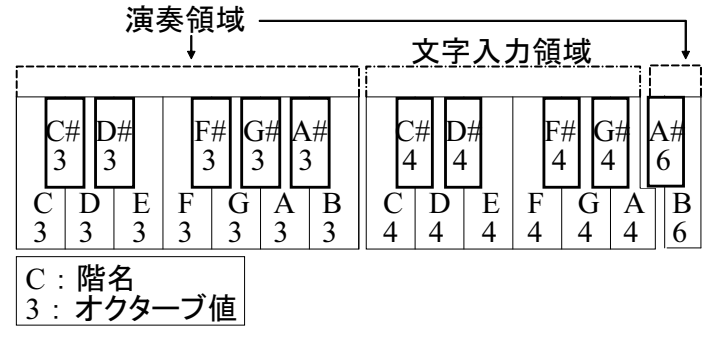

図 4 各鍵に割り当てられているノートナンバー

が可能であるが意外性がない .コード推定方式は , 両 方式の中間的な特徵をもつ手法であるが, 演奏領域で 弾いている階名以外の階名か割り当てられる可能性が あるため意外性のある演奏が可能である .

また，ランダム方式およびダイレクト方式では，演 奏領域で弾いている階名が少ない場合, 同じ階名が文 字入力領域に何度も割り当てられ，特に和音方式によ る文字入力は，和音として成り立ちにくくなる.コー ド推定方式では，この問題はおこらない．

各方式は光れぞれ特徵をもち, どれが最適が決める 


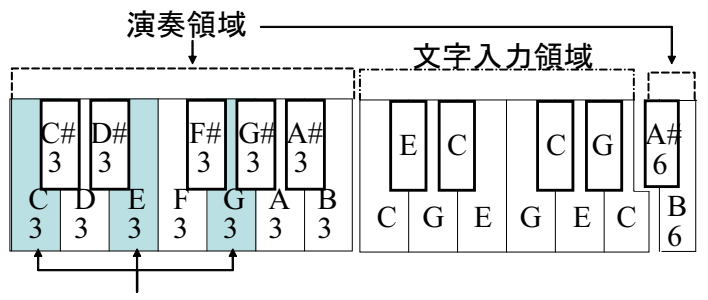

打鍵

图 5 ダイレクト方式の例

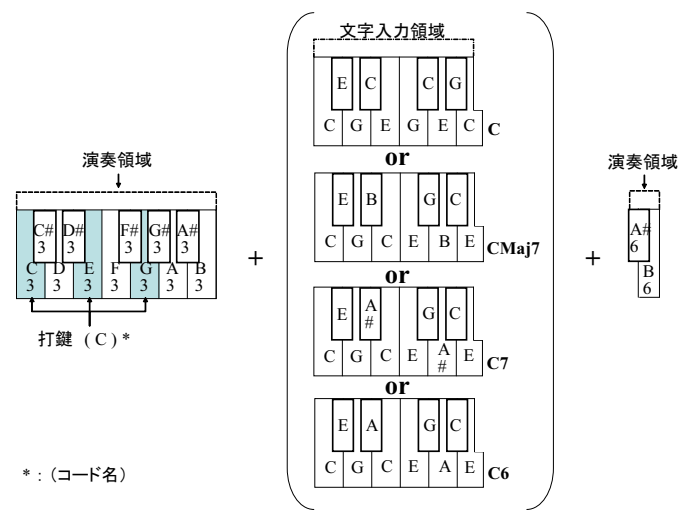

図 6 コード推定方式の例

(a)

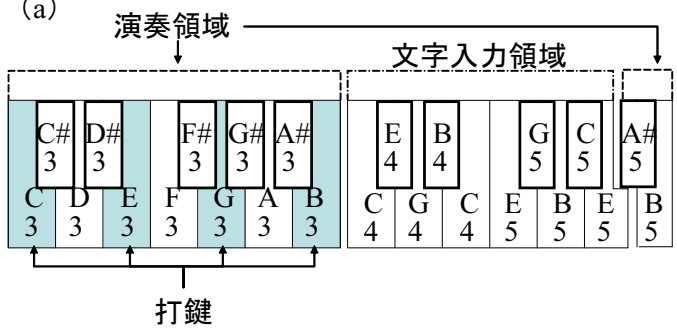

(b)

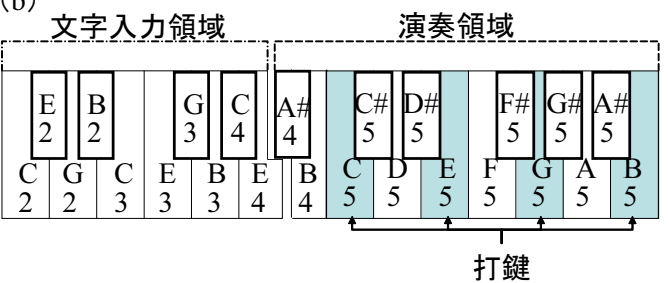

图 7 ノートナンバー置換アルゴリズムの例

ことは困難であるため，本システムではこれらの方式 を選択的に利用できるようにした .

オクターブ値の割当て

一般的なキーボードは，鍵盤上の右の鍵ほど高いピッ チが割り当てられている．弚こで，システムはこの一 般則をできるだけ守るようにオクターブ值を割り当て

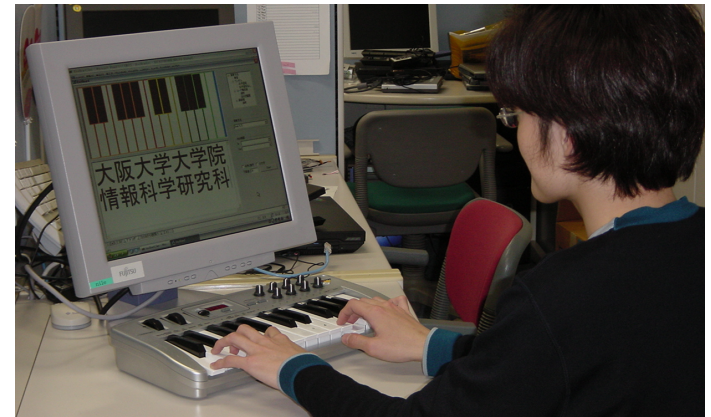

図 8 TEMPEST の利用図

る.具体的には, 図 7 (a) に示すように, 文字入力領域 の両側に演奏領域がある場合, B3 から A\#5 の音域内 でできるだけ偏りなく，かつ，上記一般則が守られる ようオクターブ値を割り当てる.また，図 7(b)に示 すように, 文字入力領域のどちらか片側にしか演奏領 域が存在しない場合, 文字入力領域と演奏領域の境界 の鍵において音高差ができるだけ小さくなるように割 り当て，光れを基準に開放されている側へ上記一般則 が守られるようにオクターブ值を割り当てる．なお， ユーザは演奏領域におけるオクターブ值を自由に割り 当てられるものとする .

\section{3. 実装}

以上に述べた TEMPEST のプロトタイプシステ ムを実装した。開発は Windows XP 上で Microsoft Visual C++.NET 2003 を用いた .プロトタイプシ ステムを用いて文字入力演奏を行っている樣子を図 8 に，一例として単音方式を用いて「大阪大学」と入力 している楽譜を図 9 に示す. 図 9 の上部楽譜はノート ナンバー変更アルゴリズムが適用されていないもので, 下部楽譜は適用されているものである . また，これは 2 オクターブの鍵盤のための楽譜で , ノートナンバー および演奏/文字入力領域の設定は図 4 のようになっ ている。

楽譜どおりに演奏すると最終的に「大阪大学」と入 力されるが, 上部楽譜は調性が不安定な音楽だが, 各 イレクト方式を適用した場合，調性が整った音楽が生 成されている.なお，提案するノートナンバー変更ア ルゴリズムは，伴奏の組み合わせによって，調性が不 安定な音楽も生成でき，ユーザは音楽を自由にコント ロールできる .

20 年以上の鍵盤演奏歴をもつ本論文の第一著者は TEMPEST を使い文字入力演奏を試みてきた．筆者 の主観であるが，鍵と光の割当て音の違いによる違 和感は，少しの練習で問題にならなくなった . また， TEMPEST は文字入力情報としてノートナンバーし か用いないため，デュナーミクやアーティキュレーショ ン，アゴーギクなどテンポや音量に関する細かい表情 付けが行え感情を豊かに表現できる.さらに，提案し た 3 つのノートナンバー変更アルゴリズムは, 状況に 応じて使い分けている . 例えば，あらかじめ作った曲 


\title{
【ノートナンバー変更アルゴリズム適用なし】
}

\author{
万力文字
}

おおえういう $\mathrm{BaBa} \quad \mathrm{BaBa}$ さなはやはな $\mathrm{BaBa} \quad \mathrm{Ba} \mathrm{Ba} \mathrm{Ba}$

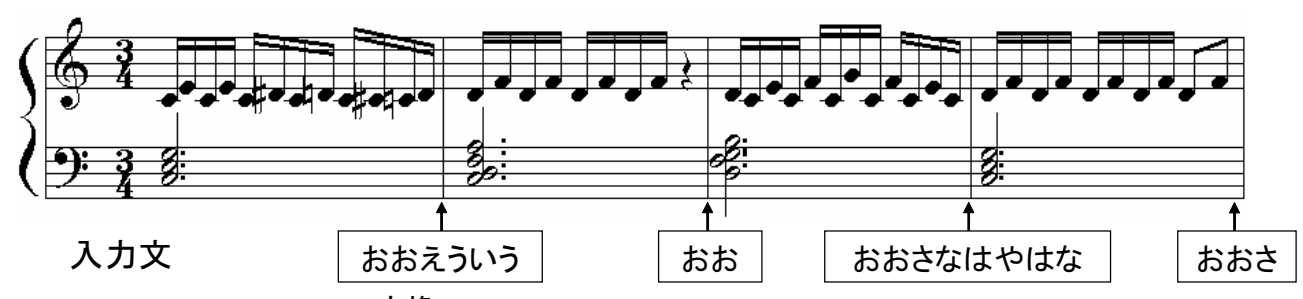

か た IC(濁音) い か IC(濁音)

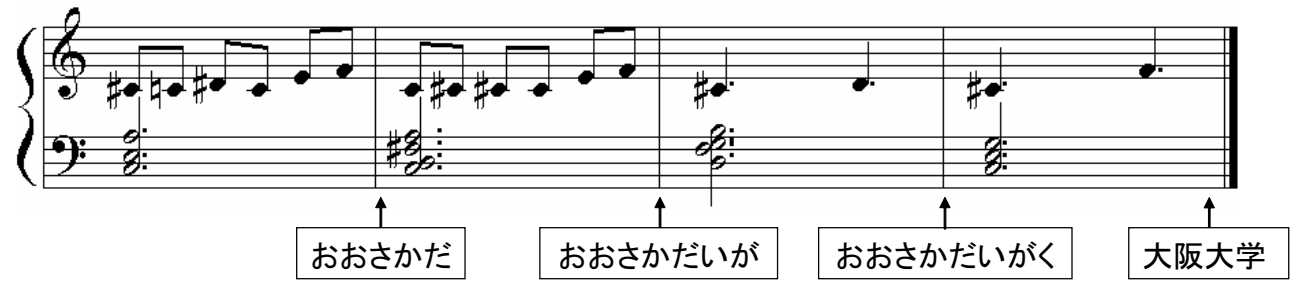

【ノートナンバー変更アルゴリズム適用ありー ダイレクト方式】
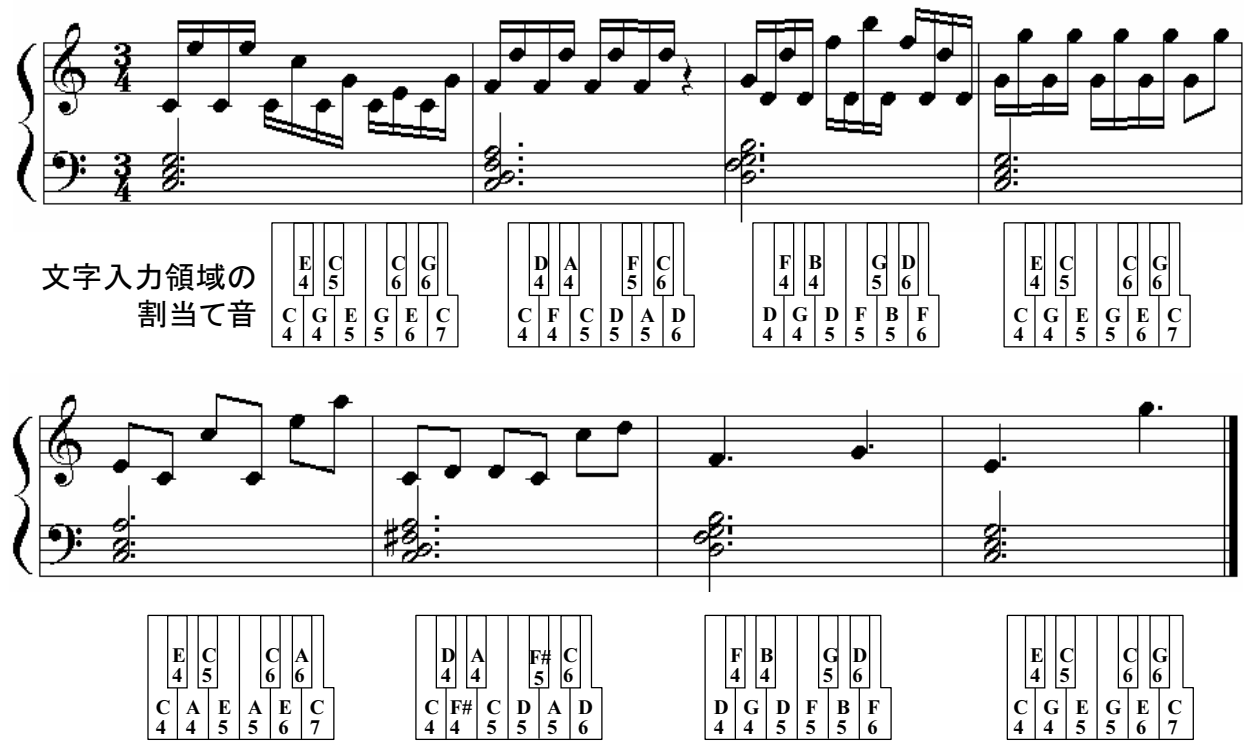

图 9 「大阪大学」を入力する楽譜

を披露する場合は，想定する音が割り当てられるダイ レクト方式をよく用い, 即興で演奏すると予想外の展 開が期待できるランダム方式やコード推定方式を使う ことが多い. 加えて, 伴奏方式は調性が限定されてし まうため表現に制約を受けるが，限定された範囲内で のコード進行は無理せず組み立てられる．また，メロ ディパートを担当することが多い右手が自由に演奏で きるため作曲しやすい .

\section{4. 評価と考察}

TEMPEST を評価する方法として，ユーザの感情 を表現できているかという入力側の評価と，演奏者の 感情が視聴者に伝わっているかという出力側の評価が 考えられる．これらの評価はいずれも客観的な指標で 測定できないため，本研究では主観評価により，感情 


\begin{tabular}{c|c|c|c|c} 
表 2 & \multicolumn{2}{c}{ 音楽性・芸術性に関するアンケートと結果 } \\
\hline 質問項目 & \multicolumn{2}{|c|}{ 音楽性 } & \multicolumn{2}{c}{ 芸術性 } \\
& 平均 & 標準偏差 & 平均 & 標準偏差 \\
\hline 適用なし & 1.66 & 1.15 & 1.22 & 0.65 \\
\hline ランダム方式 & 4.33 & 0.86 & 2.94 & 1.27 \\
\hline ダイレクト方式 & 3.99 & 1.02 & 2.41 & 1.23 \\
\hline コード推定方式 & 3.99 & 1.02 & 3.09 & 1.01 \\
\hline 伴奏方式 & 3.81 & 0.94 & 3.19 & 0.90
\end{tabular}

伝達の精度を調べた . 入力側の評価は , 演奏者個人の そも光もの表現力や，演奏スキル，文字入力スキルな どが評価に影響すると考えられ一般性のある評価が困 難である．したがって，本研究では後者の感情伝達に 関する評価に注力した。

4.1 音楽性·芸術性に関する評価

感情伝達に関する評価を行うにあたり，提案した ノートナンバー変更アルゴリズムおよび伴奏方式の有 効性および各方式間の差異について検証した . 以下， 実験の詳細について説明する .

環境

実験には Windows XP が動作するノートパソコン (IBM ThinkPad X30) を利用し, 文字表示用にプロ ジェクタを使ってスクリーン (40 インチ)に投影した 。 音源は, Roland 社の SC-8820 を, 出カスピーカは BOSE 社の小型スピーカ (MM-1), 電子鍵盤楽器は, Roland 社の OXYGEN 8 を使用した .

被験者

被験者は，筆者らが所属する大学院大学の学生 18 名に 加え，社会人，学生などウェアラブルコンピューティ ングに興味のある 20 代〜 60 代までの 24 名 . 音楽情 報科学分野の専門家 6 名の計 48 名である. 手続き

演奏者は図 9 の「大阪大学」を入力し，被験者には ノートナンバー変更アルゴリズムが適用されていない 場合と，提案した 3 つのノートナンバー変更アルゴリ ズムを適用した場合を視聴してもらった．加えて，伴 奏方式を使って同樣の文字を入力している演奏も視聴 してもらった . 伴奏方式では , 各文字に割り当てられ ているコードを音楽的につなぐために余分なコードを 挿入したため, 楽曲の長さが図 9 と比べ 2 倍程度長く なった。被験者には表 2 に示す音楽性 (不協和音，不 快な音列が含まれるなど音楽的な違和感をもったか?) と芸術性 (演奏は芸術性に優れていたか?) に関するア ンケートについて評価してもらった . また , 各評価指 標は 1 (感じない)〜 5 (感じる) の 5 段階である .

結果と考察

音楽性および芸術性において，提案方式はいずれも特 別な工夫を行っていない「適用なし」の演奏より良い 評価を得た .しかし，各提案方式間の差異はほとんど 見られなかった．また，検定を行った結果，有意水準 $1 \%$ で「適用なし」と提案方式間で有意が見られたー 方，提案方式間で有意は見られなかった。

これらの結果より，提案方式はいずれも提案方式を 適用しない場合と比較して，音楽的，芸術的に良い印 象を与えることができ，提案方式の効果を証明できた 。 また，各方式間で印象の差異はなく，感情伝達を目的 とする場合，ユユーザの嗜好によって選択的に利用して

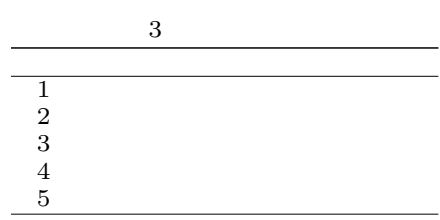

良いと言える。

\section{2 感情伝達に関する評価}

本実験では，演奏者の感情が視聴者に正確に伝わつ ているかを調査した．以下，実験の詳細について説明 する .

環境

実験には Windows XP が動作するノートパソコン (IBM ThinkPad X30) を利用し, 文字表示用にプロ ジェクタを使ってスクリーン (40 インチ) に投影した . 音源は, Roland 社の SC-8820 を, 出カスピーカは BOSE 社の小型スピーカ (MM-1), 電子鍵盤楽器は, 鍵盤数が 88 鍵の CASIO 社の PX-110 を使用した . 被験者

被験者は，筆者らが所属する大学院大学の学生 15 名 および一般人 174 名の計 189 名である.

手続き

本実験では，表 3 に示す 5 つの文章の文字入力演奏 を視聴してもらった . なお，適用した文字入力方式お よびノートナンバー変更アルゴリズムは, 予備実験に おいて差異が見られなかったため，演奏者の主観で決 めた .

実験の手順を以下に示す .

（1）演奏者があらかじめ演奏で表現したい感情を 表 4 に示す形容詞対を用いて 5 段階で得点付けする (感情マップとよゔ)

（2）被験者は各文字入力演奏を視聴し，各曲に対 して (1) と同樣の感情マップを作成する.

(3) 被験者は入力文字と演奏の雾囲気力調和して いたかを 5 段階 (5:調和している〜1:調和していない) で評価する

（4）演奏者の感情マップを被験者に提示し，被験 者は弚れに納得できるか 5 段階 $(5$ :同意できる〜 1 :同 意できない)で評価する .

（5）全ての文字入力演奏を視聴した後，被験者は 文字入力演奏が感情伝達に有効かどうか 5 段階 (5:有 効〜 1:有効でない) で評価する

（6）被験者は演奏，入力文字，演奏している樣子 など文字入力演奏全体のパフォーマンス性に関して表 5 に示すアンケートに 5 段階で評価する .

なお，表 4 に示す形容詞対は川原ら [8] の研究成果 に基づいて選出した．同論文では主成分分析から楽曲 の性質を決定づける 5 つの有意味な因子を定義し，光 れらの因子に属する特徵的な形容詞対が示されている. 実験に使用した形容詞対は，これら５つの因子に属す る形容詞対の中から適当な形容詞対を 1 対選出した . 結果

演奏者の感情伝達度を評価するために，演奏者が得点 付けした感情マップと被験者か評価した感情マップと 
芸術科学会論文誌 Vol. 6 No. 2 pp. $88-97$

表 4 演奏者の感情マップと印象誤差

\begin{tabular}{|c|c|c|c|c|c|c|}
\hline & & 5:楽しい〜1:悲しい & 5:はげしい〜1:おだやかな & 5:重い〜1:軽い & 5:すんだ〜1:にごつた & 5:安らかな〜1:不安な \\
\hline \multirow{3}{*}{1 曲目 } & 演奏者の感情 & 1 & 2 & 5 & 3 & 1 \\
\hline & 平均 & 0.40 & 0.43 & 0.69 & 0.79 & 0.49 \\
\hline & 標準偏差 & 0.60 & 0.53 & 0.78 & 0.70 & 0.59 \\
\hline \multirow{3}{*}{2 曲目 } & 演奏者の感情 & 4 & 2 & 2 & 5 & 4 \\
\hline & 平均 & 0.69 & 0.79 & 0.90 & 0.77 & 0.64 \\
\hline & 標準偏差 & 0.64 & 0.68 & 0.85 & 0.69 & 0.66 \\
\hline \multirow{3}{*}{3 曲目 } & 演奏者の感情 & 4 & 1 & 2 & 4 & 5 \\
\hline & 平均 & 0.91 & 0.41 & 0.58 & 0.63 & 0.41 \\
\hline & 標準偏差 & 0.54 & 0.62 & 0.55 & 0.59 & 0.70 \\
\hline \multirow{3}{*}{4 曲目 } & 演奏者の感情 & 2 & 4 & 4 & 3 & 2 \\
\hline & 平均 & 0.88 & 0.52 & 0.90 & 0.53 & 0.47 \\
\hline & 標準偏差 & 0.81 & 0.61 & 0.59 & 0.64 & 0.60 \\
\hline \multirow{3}{*}{5 曲目 } & 演奏者の感情 & 1 & 5 & 5 & 1 & 1 \\
\hline & 平均 & 1.05 & 0.47 & 0.69 & 0.62 & 0.51 \\
\hline & 標準偏差 & 0.88 & 0.56 & 0.61 & 0.55 & 0.66 \\
\hline \multirow[t]{2}{*}{ 全体 } & 平均 & 0.79 & 0.47 & 0.69 & 0.62 & 0.51 \\
\hline & 標準偏差 & 0.27 & 0.22 & 0.25 & 0.22 & 0.11 \\
\hline
\end{tabular}

の差の絶対値である「印象誤差」を定義する .この印 象誤差が小さいほど演奏者の感情が被験者に伝わって いることになる．演奏者が得点付けした感情マップ 各楽曲および楽曲全体における形容詞の印象誤差の平 均と標準偏差を表 4 に示す. また，実験手順 (3)〜 (6) の評価結果を表 5 および表 6 に示す.

表 4 の結果から印象誤差の平均および標準偏差は小 さく全ての楽曲において演奏者の意図する感情が被験 者に伝わっていることがわかる．また， 4 曲目の「楽 しい〜悲しい」など入力文章に関連しない形容詞の印 象誤差は, 1 曲目の「楽しい〜悲しい」など入力文章 から連想できる形容詞の印象誤差より大きくなった . このように , 入力文字が感情伝達を促進していること がわかる.

表 6(3) および (4) の結果からおおむね入力文字の意 味と演奏の雰囲気は調和していると評価され，演奏者 の感情表現にも同意を示してもらえた . 各楽曲におい て若干の差はあるが，個人差を取り除けない印象評価 において, 本実験の評価結果は, 感情伝達において有 意であることを示していると考えられる．さらに，表 $6(5)$ の結果から，演奏を交えた文字入力は感情表現に 有効だという結果が得られた .

以上の結果から，TEMPEST は演奏者の感情伝達 手段として有効なシステムであることが証明された .

加えて, 表 5 に示す文字入力演奏全体の評価結果 から，見物人に興味や没入を与える「驚き」や「面 白さ」はいずれも良い評価を得た . また，パフォーマ ンスを引き立てる上で重要な要素である「かっこよ さ」も認められた .さらに，筆者らはこれまで学会の 登壇発表 (第 55 回および第 57 回音楽情報科学研究 会 [12], [13] ,第 1 回ウェアラブルコンピューティング研 究会 $[14]$, 第 116 回ヒューマンインタフェース研究会, WISS2005) やデモ発表 (第 56 回および 67 回音楽情報 科学研究会 [16], [?] , WISS2004, ICEC2006 [25])， イ ベント (WPC EXPO 2004 [5]) などで実際に TEMPEST のデモンストレーションを行ったり，文字入力 演奏しているムービーを見てもらい，いずれも好評を 博した . 以上の結果から, TEMPEST はパフォーマ ンス性に優れているといえる .
表 5 パフォーマンス性に関するアンケート

\begin{tabular}{|c|c|c|c|}
\hline & 質問項目 & 平均 & 標準偏差 \\
\hline 面百かったか? & (5:面百い〜1:つまらない) & 4.87 & 0.33 \\
\hline 驚いたか? & (5:驚いた〜1:ありきたり) & 4.65 & 62 \\
\hline かっこいいか? & (5:良い〜 1:悪い) & 4.25 & 81 \\
\hline
\end{tabular}

表 6 感情伝達に関する評価結果

\begin{tabular}{|c|c|c|c|c|}
\hline & & 手順 (3) & 手順 (4) & 手順 (5) \\
\hline \multirow{2}{*}{1 曲目 } & 平均 & 4.43 & 4.09 & - \\
\hline & 標準偏差 & 0.77 & 0.80 & - \\
\hline \multirow[t]{2}{*}{2 曲目 } & 平均 & 3.62 & 3.17 & - \\
\hline & 標準偏差 & 0.99 & 1.08 & - \\
\hline \multirow[t]{2}{*}{3 曲目 } & 平均 & 4.43 & 4.18 & - \\
\hline & 標準偏差 & 0.77 & 0.71 & - \\
\hline \multirow[t]{2}{*}{4 曲目 } & 平均 & 3.86 & 3.45 & - \\
\hline & 標準偏差 & 1.00 & 0.97 & - \\
\hline \multirow[t]{2}{*}{5 曲目 } & 平均 & 4.26 & 4.37 & - \\
\hline & 標準偏差 & 0.93 & 0.82 & - \\
\hline \multirow[t]{2}{*}{ 全体 } & 平均 & 4.17 & 3.85 & 4.38 \\
\hline & 標準偏差 & 0.39 & 0.53 & 0.62 \\
\hline
\end{tabular}

\section{3 関 連研 究}

鍵盤楽器のメタファを利用した文字入カインタフェー スは, タイプライター [2]において古くから応用され， 例えば，ピアノに近い２段のキー配列から構成される インタフェースや，Baudot コード [1] のための $5 つ$ のキーの組み合わせで入力を行うインタフェースな どが実用化されている.他の楽器のメタファを利用し た研究事例として, Piccolo Mouse [3] や OBOE [7] , Twiddler [22] などがある .エイ・エス・インタラク ティブ社が開発した Piccolo Mouse はピッコロの運指 や関節運動をヒントに開発したマウスで人間工学的に 考えられた製品である.また, OBOE は楽器のオーボ エをメタファにしたインタフェースで, 文字入力方式 に視覚障害者が用いる点字入力方法を採用することで 高速な文字入力を実現している .さらに , ウェアラブ ルコンピューティング向けデバイスである Twiddler は , ギター演奏をメタファにしたインタフェースであ る、鍵盤楽器を利用して，MIDI データを計算機上で 編集するインタフェース [15] も提案されている.MIDI データの入力や編集において鍵盤楽器と計算機のキー ボードを併用する方式は，インタフェース間の移動や 手間を必要とするという考えから作業を鍵盤楽器のみ で行うことで効率化を図るという研究である．また， 
鍵盤楽器特有の打鍵速度を編集作業に利用することで， より効率よく感覚的に作業を行う方法について考案し ている。

これらはいずれも入力効率や入力のしやすさなどを 求めているのに対し, 本研究では芸術性に重点を置い ている点で目的が異なる .

文字入力と楽器演奏を結びつけた作品の事例として 三輪真弘氏の Send Mail [18] がある .これは, 楽器演 奏によって文字入力を行い作成された電子メールを送 信すると，送られてきたメールの文字列が MIDI ノー トナンバーに変換される作品である .この作品は, 単 純にノートナンバーと文字をマッピングしただけであ るため, 本研究のように音楽表現や伝達を考慮した文 字入力方式の工夫は行われていない .

演奏表現に注力できるシステムや楽器の事例として CiP [9] ，光るギター [4]， GraspMIDI [21] , sfp [10] な どがある. $\mathrm{CiP}$ や光るギターは, 演奏中にミスタッチ をしても正しい音に自動修正する機能をもつ．これに より，演奏者は演奏表現に集中できる．また，指揮シ ステムである GraspMIDIや $\operatorname{sfp}$ は , 音楽全体のテン ポや音量を直感的に制御できるようになっている．演 奏家がもつ表現力を活かしたいという点では本研究の コンセプトと同じであるが, 楽音レベルで演奏をコン トロールできない点や文字入力など他の要素に転用し ていない点において異なる．

\section{4 応用}

TEMPEST を用いた応用アプリケーション例として かけ合い演奏型チャツトシステムが考えられる.チャツ 卜は光れ攵れのユーザが交互に文字入力を行うため， 周囲の人から見れば，あたかもかけ合い演奏している ように見える.嬉しい・楽しいといった気持ちを表現 するために , ポップなコード進行やリズムを展開した り，寂しい・悲しいといった気持ちを伝えたいときは， マイナー調の演奏とするなどチャットに感情を含める ことが可能になる.また，ベロシティ, 音色, コード の調性に合わせてフォントサイズ，フォント，文字色 などか変わる，ある特別な入力をすると文字にスピン 効果やフェード効果といった特殊効果が加わるなどメ ディアアートへの応用が考えられる .

\section{5.おわりに}

本研究では, 文字入力に音楽表現を付加できる鍵 盤奏者のための新たな感情表現および伝達システム TEMPEST について述べた . TEMPEST は文字入力 による意図しない不協和音や，調性のゆらぎが生じな いように設計されている, さらに, 文字入力機能の独 立性を高めることで，1 つの文字に対しさまざまな奏 法 , 音高 , オクターブの高さで入力でき ,さまざまな 感情表現を付加した文字入力演奏が可能になる .また， プロトタイプによる文字入力演奏の視聴評価実験から， テキストだけの表現と比較して豊かに感情伝達できる ことが証明された .

今後はさまざまな鍵盤習熟者を対象とした試用評価 実験を行いシステムの有効性に関して評価する予定で ある .
謝辞 末筆ながら，本研究を進めるにあたって評価 実験を引き受けて下さった諸氏には有益なコメントを 多数頂いた .ここに衷心より感謝の意を表わす.なお， 本研究の一部は, 中山隼雄科学技術文化財団研究助成 および日本学術振興会科学特別研究員奨励費の支援に よるものである .ここに記して謝意を表す。

$$
\text { 文献 }
$$

[1] Baudot コードのホームページ

URL: http://en.wikipedia.org/wiki/Baudot

[2] Typewriter のホームページ .

URL: http://en.wikipedia.org/wiki/Typewriter

[3] Piccolo Mouse のホームページ .

URL: http://ascii24.com/news/i/topi/article/1998/ 07/02/print/611753.html.

[4] 光るギターのホームページ . URL: http://www.yamaha.co.jp/product/epiano-keyboard/ezeg/index.html.

[5] WPC EXPO 2004 で披露した TEMPEST に関する記事 URL: http://pcweb.mycom.co.jp/cgi-bin/print?id=24957

[6] 安部美緒子・大村和典 : 握カインタフェースによる遠隔地 間でのインフォーマルコミュニケーション, 信学技報, Vol. 99, No. 582 (2000).

[7] 雨宮智浩, 広田光一, 廣瀬通孝 : 筒型点字入カインタフェー スの開発と評価, 情報処理学会論文誌, Vol. 46, No. 7, pp. 1701-1710 (2005).

[8] 川原 浩, 野波健彦: 音楽教育研究における実験的研究 (II)享受体験におけるイメージの言語化に関する分析, 広島大 学教育学部紀要第 4 部, 26, pp. 75-85 (1997).

[9] 大島千佳, 西本一志, 宮川洋平, 白崎隆史 : 音楽表情を担 う要素と音高の分割入力による容易な MIDI シーケンス データ作成システム, 情報処理学会論文誌, Vol. 44, No. 7, pp. 1778-1790 (2003).

[10] 片寄晴弘, 奥平啓太, 橋田光代 : 演奏表情テンプレートを 利用したピアノ演奏システム：sfp，情報処理学会論文誌， Vol. 44, No. 11, pp. 2728-2736 (2003).

（11］澤田秀之，鶴丸朋史，橋本周司：GraspCom -力覚を利用 した双方向入出力デバイスの試作-, 情報処理学会インタラ クション'99 論文集, pp. 201-208 (1999).

[12] 竹川佳成, 寺田努, 塚本昌彦, 西尾章治郎: 鍵盤を用いた $\mathrm{PC}$ 用入カインタフェースの設計と実装, 情報処理学会研 究報告 (音楽情報科学研究会 2004-MUS-55)，Vol. 2004, No. 41, pp. 27-32 (2004).

[13] 竹川佳成, 寺田努, 塚本昌彦, 西尾章治郎 : 歌唱機能をも つ黑鍵追加型小型鍵盤楽器モバイルクラヴィーア IV の 設計と実装, 情報処理学会研究報告 (音楽情報科学研究 会 2004-MUS-57), Vol. 2004, No. 111, pp. 101-106 (2004).

[14] 竹川佳成, 寺田 努, 大江瑞子, 西尾章治郎：小型鍵盤を用 いた音楽活動支援システムについて, ウェアラブルコン ピューティング研究会研究報告, Vol. 1, No. 1, pp. 52-59 (2005).

[15] 中山圭, 野池賢二, 野瀬隆, 乾伸雄, 小谷, 善行 : 楽器鍵 盤による音楽情報編集システム, 情報処理学会研究報告 (音楽情報科学研究会 1996-MUS-16)，Vol. 1996, No. 1, pp. 1-6 (1996). 
[16] 竹川佳成, 寺田努, 塚本昌彦, 西尾章治郎：鍵盤を用いた芸 術的な PC 操作, 情報処理学会研究報告 (音楽情報科学研 究会 2004-MUS-56), Vol. 2004, No. 56, p. 29 (京都大 学, 京都, 2004 年 8 月).

[17] 竹川佳成, 寺田 努, 西尾章治郎: TEMPEST: 音楽表現が 可能な文字入力支援システム, 情報処理学会研究報告 (音楽 情報科学研究会 2006-MUS-67), Vol. 2006, No. 113, p. 11, デモ発表 (関西学院大学梅田キャンパス, 大阪, 2006 年 10 月).

[18] 三輪眞弘 : 出品作品”Send Mail”について -ある作曲家 が体験したピッチ検出の実際と限界 - , 情報処理学会研 究報告 (音楽情報科学研究会 1996-MUS-19), Vol. 1997, No. 18 , pp. 47-48 (1997).

[19] 山田裕子, 平野貴幸, 西本一志: TangibleChat: 打鍵振動 の伝達によるキーボードチャットにおける対話状況アウェ アネス伝達の試み, 情報処理学会論文誌, Vol. 44, No. 5, pp. 1392-1403 (2003).

[20] E. Mynatt, J. Rowan, S. Graighill, and A. Jacobs.: Digital Family Portraits: Providing Peace of Mind for Extended Family Members., Proc. Conference on Human factors in computing systems (CHI 2001), pp. 333-340 (2001).

[21] H. Sawada, N. Onoe and S. Hashimoto.: Sounds in Hands - A Sound Modifier Using Datagloves and Twiddle Interface -., Proc. International Computer Music Conference (ICMC 1997), pp. 309-312 (1997).

[22] K. Lyons, D. Plaisted, and T. Starner.: Expert Chording Text Entry on the Twiddler One-Handed Keyboard., Proc. IEEE International Symposium on Wearable Computers (ISWC2004), pp. 94-101 (2004).

[23] T. Yoshino, T. Muta, and J. Munemori.: Namba: Location-Aware Collaboration System for Shopping and Meeting., IEEE Trans. on Consumer Electronics, Vol. 48, No. 3, pp. 470-477 (2002).

[24] Y. Itoh, A. Miyajima, and T. Wanatabe.: 'TSUNAGARI' Communication: Fostering a Feeling of Connection Between Family Members., Proc. Conference on Human factors in computing systems (CHI 2002), pp. 810-811 (2002).

[25] Y. Takegawa, T. Terada, and S. Nishio: TEMPEgT: A Text Input System for Musical Performers., Proc. of Int'l Conf. on Entertainment Computing (ICEC 2006), pp. 322-325 (2006).

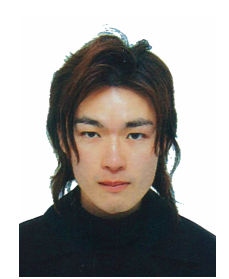

\section{竹川佳成}

2003 年三重大学工学部情報工学科卒業. 2005 年大阪大学大学院情報科学研究科修 士課程修了. 現在, 同大学院情報学研究科 マルチメディア工学専攻博士後期課程に在 籍.音楽情報科学, ウェアラブルコンピュー ティングの研究に従事 . 情報処理学会 , 日 本データベース学会の会員 .

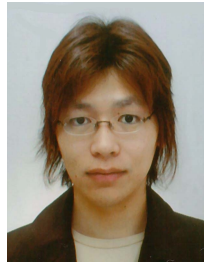

\section{寺田努}

1997 年大阪大学工学部情報システム工 学科卒業. 1999 年同大学院工学研究科博 士前期課程修了. 2000 年同大学院工学研 究科博士後期課程退学. 同年より大阪大学 サイバーメディアセンター助手 . 2005 年 より同講師 . 現在に至る. 2002 年より同 大学院情報科学研究科マルチメディア工学専攻助手, 2005 年 より同講師を併任 . 2004 年より特定非営利活動法人ウェアラ ブルコンピュータ研究開発機構理事, 2005 年より同機構事務 局長を兼務. 工学博士 . アクティブデータベース，ウェアラブ ルコンピューティング, ユビキタスコンピューティングの研究 に従事. IEEE, 情報処理学会, 電子情報通信学会, 日本デー タベース学会の各会員 .

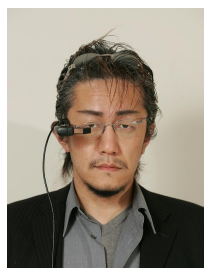

\section{塚本昌彦}

1987 年京都大学工学部数理工学科卒業. 1989 年同大学院工学研究科修士課程修了. 同年 , シャープ (株) 入社 . 1995 年大阪大 学大学院工学研究科情報システム工学専攻 講師，1996 年同専攻助教授となる. 2002 年より同大学院情報科学研究科マルチメ ディア工学専攻助教授となる . 2004 年より神戶大学工学部電 気電子工学科教授, 2007 年より同大学大学院工学研究科電気 電子工学専攻教授となり，現在に至る.工学博士 . ウェアラブ ルコンピューティングおよびユビキタスコンピューティングに 興味を持つ. ACM , IEEE 等 8 学会の会員.

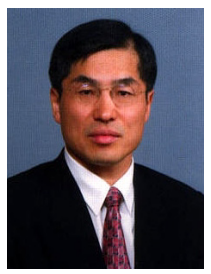

\section{西尾章治郎}

1975 年京都大学工学部数理工学科卒業. 1980 年同大学院工学研究科博士後期課程 修了. 工学博士. 京都大学工学部助手, 大 阪大学基礎工学部および情報処理教育セン ター助教授, 大阪大学大学院工学研究科情 報システム工学専攻教授を経て, 2002 年 より同大学院情報科学研究科マルチメディア工学専攻教授とな り, 現在に至る . 2000 年より大阪大学サイバーメディアセン ター長, 2003 年より大阪大学大学院情報科学研究科長を併任. この間, カナダ・ウォータールー大学, ビクトリア大学客員 . データベース, マルチメディアシステムの研究に従事 . 現在 , Data \& Knowledge Engineering 等の論文誌編集委員 . 情報 処理学会フェロー，電子情報通信学会フェローを含め, $\mathrm{ACM}$, IEEE など 8 学会の会員 . 